\title{
Neurological, Electroencephalographic, and Virological Findings in Febrile Children
}

\author{
SHEILA J. WALLACE* and HELEN ZEALLEY \\ From the Department of Child Life and Health, University of Edinburgh; and the City Hospital, Edinburgh \\ Wallace, S. J., and Zealley, H. (1970). Archives of Disease in Childhood, 45, 611. \\ Neurological, electroencephalographic, and virological findings in febrile \\ children. Investigations were made of 78 febrile children, 53 with fits and 25 \\ without fits. $53 \%$ of the children with fits had viral illnesses. Severe fits were \\ commoner in these children than in those with negative viral findings. Per- \\ manent neurological damage and prolonged EEG abnormalities were found signifi- \\ cantly more often in children with, than in those without, viral disease, whether or \\ not fits had occurred. The long-term implications are discussed. In addition to \\ viral agents already described as causing neurological complications, the following \\ organisms were found in association with central nervous system disorder: \\ adenovirus 7, respiratory syncytial virus, parainfluenza 2 , and $C$. burnetii \\ ( $Q$ fever).
}

During an investigation into factors involved in convulsions associated with febrile illness in childhood, it became apparent that a convulsion was likely to be a symptom of an illness for which no bacteriological cause could be found. In order to assess the extent to which viruses were involved, and their influence on neurological and electroencephalographic (EEG) findings, virological investigations were undertaken on convulsing children admitted to the Royal Hospital for Sick Children, Edinburgh. The findings in 53 of these children, and in a further 25 children who were febrile, but who had not had fits, and whose data are used for control purposes, are presented.

\section{Patients and Methods}

The children are divided into four groups dependent on the presence or absence of fits and the viral findings. Group $A: 28$ children with fits and positive viral findings. Group $B: 25$ children with fits and negative viral findings. Group $C: 18$ control children with positive viral findings. Group D: 7 control children with negative viral findings.

All 78 children were aged from more than 1 month to less than 7 years on admission to hospital. The numbers in groups $\mathrm{A}, \mathrm{B}, \mathrm{C}$, and $\mathrm{D}$ according to age and sex are shown in Table $I$.

The children with fits were seen between November 1965 and August 1966, and the control children between

Received 25 March 1970

$\star$ Present address: Spina Bifida Unit, Cardiff Royal Infirmary.
September 1966 and November 1967. This was the first convulsive episode for all 53 children who had fits and all showed evidence of a concurrent infection. The control children were selected on the basis of age, no previous or present history of a convulsion, and the presence of a pyrexia equal to, or greater than, $37 \cdot 8^{\circ} \mathrm{C}$. (100 ${ }^{\circ} \mathrm{F}$.) during an infective illness. Though some children had evidence to suggest prior neurological damage, in no case was this severe enough to have caused parental comment. Full birth, developmental, and family histories were taken in all cases where the mother was available; and, in addition, birth notes were consulted if the child had been born in hospital.

A general clinical examination with special reference

TABLE I

Ages at Admission, and Sex Incidence

\begin{tabular}{|c|c|c|c|c|}
\hline $\begin{array}{l}\text { Age at Time of } \\
\text { Admission }\end{array}$ & $\begin{array}{c}\text { Group A } \\
\text { (28 cases) }\end{array}$ & $\begin{array}{l}\text { Group B } \\
(25 \text { cases })\end{array}$ & $\begin{array}{l}\text { Group C } \\
\text { (18 cases) }\end{array}$ & $\begin{array}{l}\text { Group D } \\
\text { (7 cases) }\end{array}$ \\
\hline $\begin{array}{l}<6 \text { mth. } \\
6 \text { mth. }<1 \text { yr. } \\
1 \text { yr. }<1 \frac{1}{2} \text { yr. } \\
1 \frac{1}{2} \text { yr. }<<2 \text { yr. } \\
2 \text { yr. }<3 \text { yr. } \\
3 \text { yr. - < } 4 \text { yr. } \\
4 \text { yr. - < } 5 \text { yr. } \\
5 \text { yr. - < } 7 \text { yr. }\end{array}$ & $\begin{array}{l}0 \\
7 \\
6 \\
3 \\
5 \\
3 \\
2 \\
2\end{array}$ & $\begin{array}{l}0 \\
4 \\
5 \\
6 \\
7 \\
0 \\
1 \\
2\end{array}$ & $\begin{array}{l}1 \\
4 \\
2 \\
2 \\
2 \\
3 \\
0 \\
4\end{array}$ & $\begin{array}{l}1 \\
1 \\
1 \\
1 \\
2 \\
0 \\
1 \\
0\end{array}$ \\
\hline \multicolumn{5}{|l|}{ Sex incidence } \\
\hline $\begin{array}{l}\text { Male } \\
\text { Female }\end{array}$ & $\begin{array}{l}17 \\
11\end{array}$ & $\begin{array}{r}16 \\
9\end{array}$ & $\begin{array}{r}10 \\
8\end{array}$ & $\begin{array}{l}4 \\
3\end{array}$ \\
\hline
\end{tabular}


to the central nervous system was performed as soon after admission as possible, and always within 6 hours. The neurological examination was repeated at least once a day until it became normal or the child was discharged home. The children with fits were re-examined regularly as out-patients for up to two and a half years, and 6 of the controls were seen once after discharge, but no attempt was made to follow them further.

Eight-channel EEG recordings were obtained with the use of either an A.E.I. Polygraph or an Offner type T machine. Only records taken with the child awake are included in this report. Electrode placements were in the lateral position, using the 10-20 system (see Fig. 3 and 4). The paper speed was $3 \mathrm{~cm}$. $/ \mathrm{sec}$., the time constant $0.3 \mathrm{sec}$. and the amplitude $50 / \mu \mathrm{V} / 0.5 \mathrm{~cm}$. throughout recording. The first tracing was recorded within 6 hours of the child's fit or admission (in control children) in 23 cases, and within 24 hours of fit or admission in a total of 67 children. The other 11 children, 10 of whom had had fits, had their first record taken within 4 days. The convulsing children (groups $A$ and $B$ ) had their records repeated twice daily for 48 hours, then daily until a normal record was obtained or the child was discharged home. 24 control children (groups $\mathrm{C}$ and $\mathrm{D}$ ) had a second record taken more than 24 hours after they became afebrile. (The mother of Case $\mathrm{C} 24$ refused permission for a repeat record.) 12 of the control children, who had had abnormal tracings, had 3 or more records taken.

\section{Virological methods.}

Specimens: (i) Pharyngeal swabs: these were obtained from all children within 24 hours of admission. They were immersed immediately in transport medium, consisting of medium 199 with added bovine albumin, sodium bicarbonate, and antibiotics.

(ii) Stool specimens: these were obtained from 36 convulsers and 15 controls as soon after admission as possible. They were homogenized in transport medium with glass beads and then centrifuged. Antibiotics were added to the supernatant.

(iii) Paired sera: these were obtained from 53 convulsers and 24 controls. The acute serum was taken within 24 hours of admission, and the time interval between the acute and convalescent sera varied from 7 to 37 days.

Viral culture. Pharyngeal swabs and stool specimens were stored at $-70^{\circ} \mathrm{C}$. until tissue cultures were available. They were inoculated on to $\mathrm{HEp}-2$ and second-pass monkey kidney cells, rolled at $34^{\circ} \mathrm{C}$., and examined for cytopathic effect three times a week. After 10 days each specimen was passaged at least once and haemadsorption tests using human ' 0 ' cells were performed on all monkey kidney cultures of pharyngeal swabs at the end of the second passage.

Viruses were identified with neutralizing sera from the Standards Laboratory for Serological Reagents, Colindale, London.

Serological technique. Paired sera were stored at $-20^{\circ} \mathrm{C}$. on arrival at the laboratory and tested together for complement-fixing antibodies by a technique based on that described by Bradstreet and Taylor (1962). Sera were only titrated if antibodies were found to be present at a dilution of 1:16. The following antigens were used at the recommended dilution: influenza $\mathrm{A}, \mathrm{B}$, and C, Sendai, parainfluenza 1, 2, and 3, adenovirus, respiratory syncytial virus (RSV), mumps, measles, psittacosis, Coxiella burnetii, and Mycoplasma pneumoniae. All antigens and standard antisera were obtained from the Standards Laboratory, with the exception of parainfluenza 1 which was obtained from Burroughs Wellcome Ltd. and parainfluenza 2 and 3 from Microbiological Associates Ltd.

When antibodies to viruses isolated from the children could not be measured by the complement-fixation method, neutralizing antibodies were measured as described by Grist et al. (1966).

\section{Findings}

Birth history. In each group, the numbers with normal and abnormal perinatal findings are shown in Table II. Abnormalities of pregnancy, labour, and delivery were commoner in groups $\mathbf{A}$ and $B$ than in groups $C$ and $D$, and fetal distress in labour followed by abnormal delivery was most common in group $B$ patients. There were abnormal neonatal findings in a surprisingly large number of cases in all groups.

Developmental history. In 75 children the crude motor milestones were achieved within the expected times (Neligan and Prudham, 1969). 27 group A children, 24 group B children, 17 group C children, and all 7 group D children were sitting unsupported by 10 months or walking alone by 19 months.

Evidence of earlier neurological damage. Details of the 21 patients in whom this was present are given in Table III. $81 \%$ of these patients belong to groups $\mathrm{A}$ and $\mathrm{B}$, as compared with $68 \%$ of all the children $\left(\chi^{2}=1 \cdot 45\right.$, not significant). No child in group $\mathrm{D}$ was thought to have previous damage. Apart from the two children in group $\mathrm{C}$ with diplegia, all those with pyramidal tract damage were found in groups $A$ and $B$. There was no significant difference between the numbers in groups A and B. Fig. 1 shows a group B child with the typical hand posture of a mild left hemiplegia. His mother never commented on his reduced use of the left hand.

Family history. The histories of fits for first degree relatives are shown in Table IV. In both 
TABLE II

\section{Birth Histories}

\begin{tabular}{|c|c|c|c|c|c|c|c|c|c|}
\hline \multicolumn{6}{|c|}{ Birth Details } & $\begin{array}{r}\text { Group A } \\
\text { (28 cases) }\end{array}$ & $\begin{array}{l}\text { Group B } \\
(25 \text { cases })\end{array}$ & $\begin{array}{l}\text { Group C } \\
\text { (18 cases) }\end{array}$ & $\begin{array}{l}\text { Group D } \\
\text { ( } 7 \text { cases) }\end{array}$ \\
\hline Normal pregnancy & . & . & $\cdots$ & . & $\cdots$ & 13 & 14 & 14 & 6 \\
\hline $\begin{array}{l}\text { Abnormal pregnancy } \quad . \\
\text { Threatened abortion } \ldots \\
\text { Ante-partum haemorrhage } \\
\text { Pre-eclampsia } \quad . . \\
\text { Urinary infection } \quad \ldots \\
\text { Treatment: epilepsy or depr }\end{array}$ & $\begin{array}{l}\cdots \\
\cdots \\
\cdots \\
\cdots \\
\text { ession }\end{array}$ & $\begin{array}{l}\cdots \\
\cdots \\
\cdots \\
\cdots\end{array}$ & $\begin{array}{l}\cdots \\
\cdots \\
\cdots \\
\cdots \\
\cdots\end{array}$ & $\begin{array}{l}\cdots \\
\cdots \\
\cdots \\
\cdots \\
\cdots\end{array}$ & $\begin{array}{l}\cdots \\
\cdots \\
\cdots \\
\cdots \\
\cdots\end{array}$ & $\begin{array}{r}15 \\
3 \\
1 \\
9 \\
4 \\
4\end{array}$ & $\begin{array}{r}11 \\
3 \\
2 \\
4 \\
3 \\
2\end{array}$ & $\begin{array}{l}4 \\
2 \\
1 \\
3 \\
0 \\
0\end{array}$ & $\begin{array}{l}1 \\
0 \\
0 \\
1 \\
0 \\
0\end{array}$ \\
\hline Normal labour and delivery & . & . & . & . & $\cdots$ & 22 & 17 & 17 & 6 \\
\hline $\begin{array}{l}\text { Abnormal labour or delivery } \\
\text { Prolonged labour: more than } \\
\text { Forceps delivery } \quad . \\
\text { Caesarean section } \quad . \\
\text { Fetal distress in labour }\end{array}$ & $\begin{array}{l}\cdots \\
24 \text { hr. } \\
\cdots \\
\cdots \\
\cdots\end{array}$ & $\begin{array}{l}\cdots \\
\cdots \\
\cdots \\
\cdots\end{array}$ & $\begin{array}{l}\cdots \\
\cdots \\
\cdots \\
\cdots\end{array}$ & $\begin{array}{l}\cdots \\
\cdots \\
\cdots \\
\cdots\end{array}$ & $\begin{array}{l}\cdots \\
\cdots \\
\cdots \\
\cdots\end{array}$ & $\begin{array}{l}6 \\
3 \\
2 \\
2 \\
4\end{array}$ & $\begin{array}{l}8 \\
0 \\
3 \\
4^{\star} \\
5\end{array}$ & $\begin{array}{l}1 \\
0 \\
0 \\
0 \\
1\end{array}$ & $\begin{array}{l}1 \\
0 \\
0 \\
0 \\
1\end{array}$ \\
\hline Normal neonatal findings & . & . & . & . & $\cdots$ & 18 & 14 & 10 & 5 \\
\hline $\begin{array}{l}\text { Abnormal neonatal findings } \\
\text { Birthweight less than } 2268 \mathrm{~g} \\
\text { Apnoea at birth } \\
\text { Drowsiness or irritability }\end{array}$ & $\begin{array}{l}\cdots \\
\cdots \\
\cdots\end{array}$ & $\begin{array}{l}\cdots \\
\cdots \\
\cdots\end{array}$ & $\begin{array}{l}\cdots \\
\cdots \\
\cdots \\
\cdots\end{array}$ & $\begin{array}{l}\cdots \\
\cdots \\
\cdots \\
\cdots\end{array}$ & \begin{tabular}{l|}
$\cdots$ \\
$\cdots$ \\
$\cdots$
\end{tabular} & $\begin{array}{l}10 \\
3 \\
7(1) \\
1\end{array}$ & $\begin{array}{l}11 \\
1 \\
9(3) \\
3\end{array}$ & $\begin{array}{l}8 \\
2 \\
6(1) \\
3\end{array}$ & $\begin{array}{l}2 \\
0 \\
1(0) \\
2\end{array}$ \\
\hline
\end{tabular}

Figures in parenthesis indicate babies intubated.

* Includes 2 elective sections.

TABLE III

Patients with Prior Neurological Damage

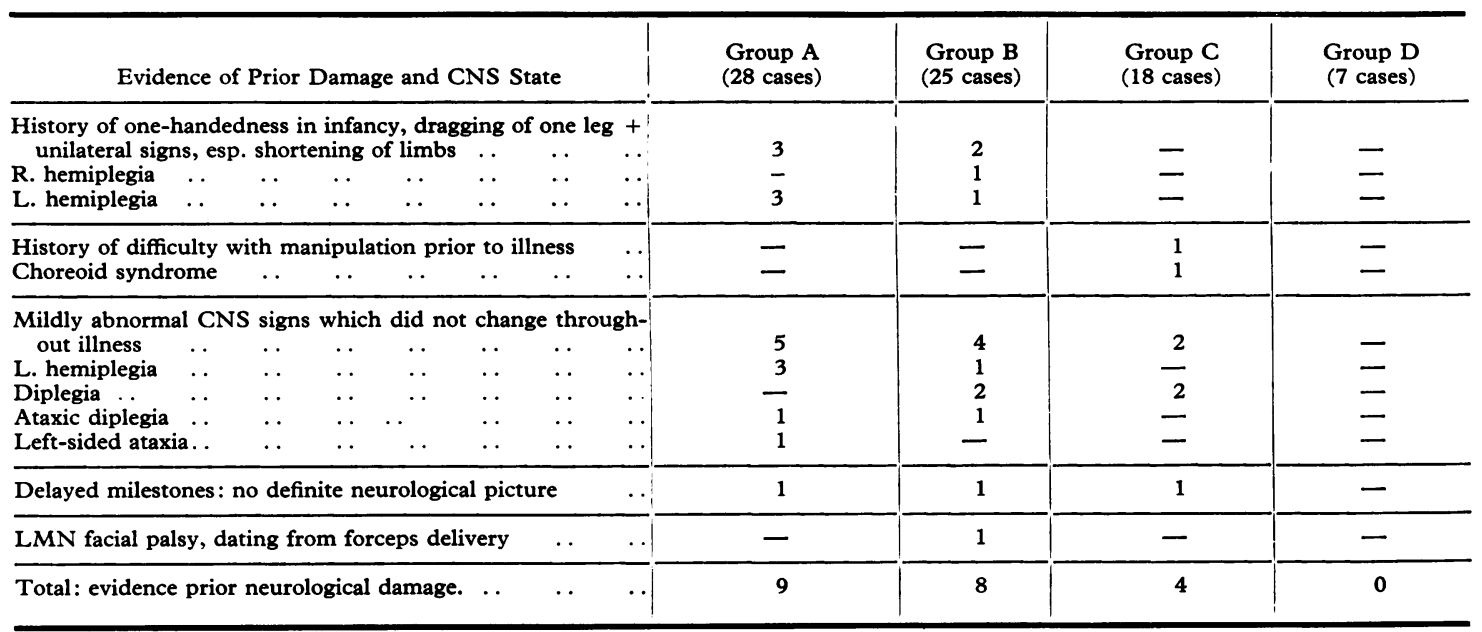

$\mathrm{LMN}=$ lower motor neurone.

sibs and parents, there were more positives in groups $A$ and $B$ than in groups $C$ and $D$, but in neither category were the differences significant (Sibs $\chi^{2}=1 ;$ parents $\chi^{2}=1 \cdot 1$ ).

General clinical examination. The clinical diagnoses are shown in Table V. Respiratory tract disease was the commonest finding in all groups, but it was almost exclusively confined to the upper respiratory passages (URTI) in groups $A$ and $B$. Despite negative viral findings, encephalitis was diagnosed in four group B patients on the basis of persistent drowsiness, acquisition of abnormal neurological signs during the illness, increased lymphocytes in the cerebrospinal fluid, and/or worsening of the EEG without further fits. 


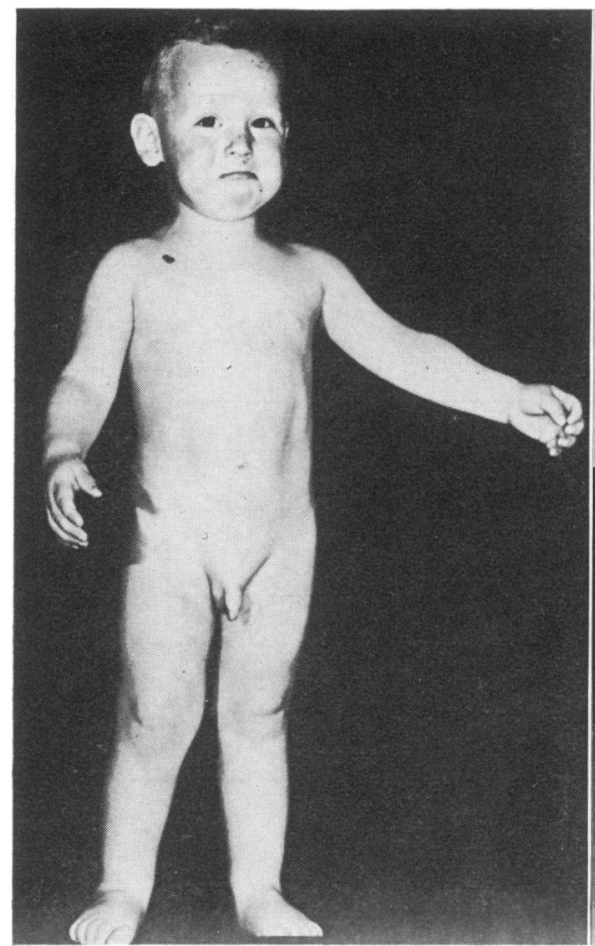

FIG. 1.

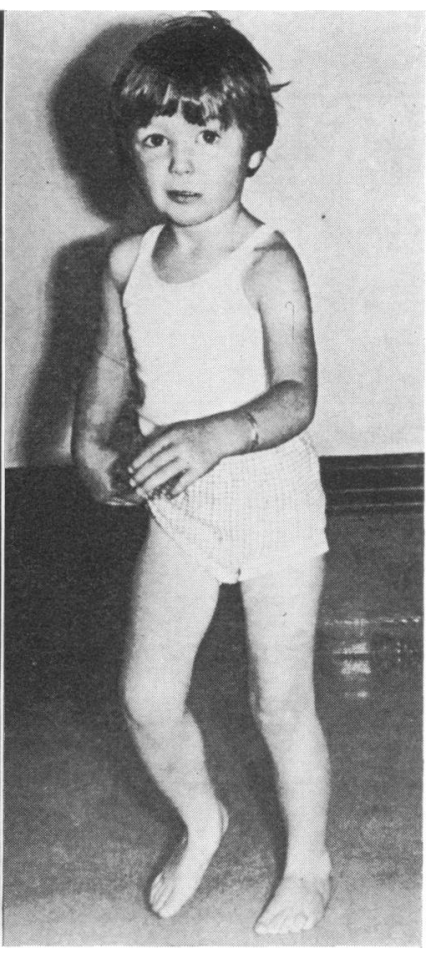

FIG. 2.

FIG. 1.-Case 128. Minimal left hemiplegia.

FIG. 2.-Case 143. Acquired right hemiplegia and left facial palsy.

Lumbar puncture. This was performed on all children in groups $A$ and $B$. In group $A, 2$ children in whom $C$. burnetii infection was diagnosed had increased polymorphonuclear leucocytes in the CSF and a third, with mumps meningoencephalitis, had large numbers of lymphocytes. In group B, 2 children with clinical encephalitis had raised lymphocyte counts. All specimens were sterile on

TABLE IV

Family Histories

\begin{tabular}{c|c|c|c|c}
\hline Family Group & $\begin{array}{c}\text { Group A } \\
(28 \text { cases })\end{array}$ & $\begin{array}{c}\text { Group B } \\
\text { (25 cases) }\end{array}$ & $\begin{array}{c}\text { Group C } \\
\text { (18 cases) }\end{array}$ & $\begin{array}{c}\text { Group D } \\
\text { (7 cases) }\end{array}$ \\
\hline $\begin{array}{c}\text { Sibs: } \\
\text { Total with sibs } \\
\begin{array}{c}\text { Total with sibs } \\
\text { with fits }\end{array}\end{array}$ & 24 & 18 & 15 & 6 \\
\hline $\begin{array}{l}\text { Parents: } \\
\text { Total parents: } \\
\text { Known histories }\end{array}$ & 52 & 50 & 1 & 1 \\
\hline $\begin{array}{c}\text { Parents with fits } \\
\text { (2) }\end{array}$ & 6 & 8 & 36 & 12 \\
\hline
\end{tabular}

bacterial culture. The 5 children injgroup $C$ who had it examined had normal CSF, and the only child in group $\mathrm{D}$ to have a lumbar puncture had Haemophilus influenzae meningitis.

Viral findings. Children were diagnosed as having had a viral illness if they showed a fourfold or greater rise in antibody titre, with or without

TABLE V

Clinical Diagnoses

\begin{tabular}{l|c|c|c|c}
\hline Clinical Diagnosis & $\begin{array}{c}\text { Group A } \\
\text { (28 cases) }\end{array}$ & $\begin{array}{c}\text { Group B } \\
\text { (25 cases) }\end{array}$ & $\begin{array}{c}\text { Group C } \\
\text { (18 cases) }\end{array}$ & $\begin{array}{c}\text { Group D } \\
\text { (7 cases) }\end{array}$ \\
\hline $\begin{array}{l}\text { Upper respiratory } \\
\text { tract infection } \\
\text { Lower respiratory } \\
\begin{array}{l}\text { tract infection } \\
\text { Encephalitis }\end{array}\end{array}$ & 16 & 17 & 7 & 2 \\
$\begin{array}{l}\text { Measles } \\
\text { Others }\end{array}$ & 0 & 2 & 9 & 2 \\
& 4 & 4 & 1 & 0 \\
\hline
\end{tabular}

*Urinary infection 1 , erysipelas 1 .

†Stomatitis 1.

¥Septic arthritis $1, H$. influenzae meningitis 1 , appendix abscess 1 . 
isolation of the same virus, or if they had a significantly raised stable titre (Communicable Diseases, Scotland, Report, 1967). Virus infections were found in $53 \%$ (28) of the children with fits (groups $A$ and $B$ ), and $72 \%$ (18) of the controls (groups C and D) $\left(x^{2} 2 \cdot 6\right.$, not significant).

Infections with the following viruses were identified in association with convulsions or clinical evidence of acquired neurological damage without convulsions: polioviruses 1,2 , and 3 , adenovirus, RSV, measles, herpes simplex, influenza $A, B$, and C, parainfluenza 2 and 3, mumps, $M$. pneumoniae, C. burnetii, and Coxsackie B2, B3, and B4.

Table I shows that in groups $A$ and $B$, and even more so in groups $C$ and $D$, virus infections were diagnosed more often in the oldest and youngest ages.

Fits. The type, duration, and number of fits in children in groups A and B are shown in Table VI: firstly in all 53 children, and, secondly, in the 36 who had no evidence to suggest prior neurological damage. 13 group A children, and 8 group B children with no prior neurological damage had either focal fits or repeated or prolonged generalized fits $\left(\chi^{2} 0 \cdot 9\right.$, not significant).

TABLE VI

Type of Fits

\begin{tabular}{|c|c|c|}
\hline All 53 Children with Fits & $\begin{array}{l}\text { Group A } \\
(28 \text { cases })\end{array}$ & $\begin{array}{l}\text { Group B } \\
(25 \text { cases })\end{array}$ \\
\hline $\begin{array}{l}\text { Focal Total } \\
\text { Single fit lasting less than } \frac{1}{2} \text { hour } \\
\text { Single fit lasting more than } \frac{1}{2} \text { hour } \\
\text { Multiple fits, regardless of duration }\end{array}$ & $\begin{array}{r}11 \\
2 \\
4 \\
5\end{array}$ & $\begin{array}{l}7 \\
3 \\
3 \\
1\end{array}$ \\
\hline $\begin{array}{l}\text { Generalized Total } \\
\text { Single fit lasting less than } \frac{1}{2} \text { hour } \\
\text { Single fit lasting more than } \frac{1}{2} \text { hour } \\
\text { Multiple fits, regardless of duration }\end{array}$ & $\begin{array}{r}17 \\
9 \\
4 \\
4\end{array}$ & $\begin{array}{r}18 \\
14 \\
3 \\
1\end{array}$ \\
\hline \multicolumn{3}{|l|}{$\begin{array}{l}\text { Children with no evidence of prior } \\
\text { neurological damage ( } 36 \text { cases) }\end{array}$} \\
\hline $\begin{array}{l}\text { Focal } \\
\text { Single fit lasting less than } \frac{1}{2} \text { hour } \\
\text { Single fit lasting more than } \frac{1}{2} \text { hour } \\
\text { Multiple fits, regardless of duration }\end{array}$ & $\begin{array}{l}8 \\
0 \\
4 \\
4\end{array}$ & $\begin{array}{l}4 \\
3 \\
1 \\
0\end{array}$ \\
\hline $\begin{array}{l}\text { Generalized Total } \\
\text { Single fit lasting less than } \frac{1}{2} \text { hour } \\
\text { Single fit lasting more than } \frac{1}{2} \text { hour } \\
\text { Multiple fits, regardless of duration }\end{array}$ & $\begin{array}{r}11 \\
6 \\
2 \\
3\end{array}$ & $\begin{array}{r}13 \\
9 \\
3 \\
1\end{array}$ \\
\hline
\end{tabular}

Neurological findings. The EEG findings in the first four days and the viral, bacteriological, or clinical diagnosis, and the neurological findings in all groups are summarized in Table VII (A, B, C, and D).
Group A. (Table VIIA) Of the 9 children with prior neurological damage, 2 showed temporary deterioration in association with their illnesses. Two children acquired left hemiplegias which recovered during convalescence. Except for fits, 5 had no evidence of neurological abnormality at any stage. 12 children acquired unremitting signs, and of these, 2 developed mixed lesions. The right hemiplegia and left facial palsy of Case 143 are shown in Fig. 2.

In 3 children (Cases 137, 142, and 145) abnormal signs which were not present on admission developed during the course of the illness.

Cases 98, 137, 143, 145, and 148 showed moderate to severe disability as a result of their hemiplegias.

Group $B$. (Table VIIB). Of the 8 patients with previous neurological damage, 3 had temporary deterioration of their lesions. None of the children with acquired abnormal neurological signs had positive bacteriology. Temporary damage occurred in 8 patients. Unremitting signs were found in 5 children, 3 of whom had encephalitis diagnosed clinically. Case 96, in addition to objective neurological signs, had severe reading and writing retardation despite an IQ of 100. Apart from fits, 4 children showed no evidence of neurological damage at any time.

Group C. (Table VIIC). Of the 4 children with previous neurological damage, one showed deterioration during his illness. Temporary damage was acquired in 5 children, and permanent damage appeared in four. 5 showed no evidence of neurological damage at any time.

Group D. (Table VIID). Case C10 was the only child in this group to show any abnormal neurological signs.

$E E G$ findings. The findings in the 'worst' and 'best' EEGs recorded in the first 4 days after admission to hospital are summarized in Table VII (A, B, C, and D). If only one EEG was recorded during this time, it is placed under 'worst', since almost all single records were taken within 24 hours of the child's admission. The numbers and percentages of specific findings in each group are given in Table VIII.

From the Tables, it will be seen that slowing of background activity, especially if it was moderate or severe, was more commonly found and more persistent in groups $A$ and $C$ than in groups $B$ and $\mathrm{D}$, but the difference is not quite significant at the $5 \%$ level. ('Worst' records: $\chi^{2} 3 \cdot 1$, 'best' records: $\chi^{2} 3 \cdot 3$.) Asymmetry of background activity was virtually confined to groups A and B. Runs of activity slower than the background occurred commonly in the febrile stages in all groups, but 
Group A; Neurological, EEG, and Virologizal

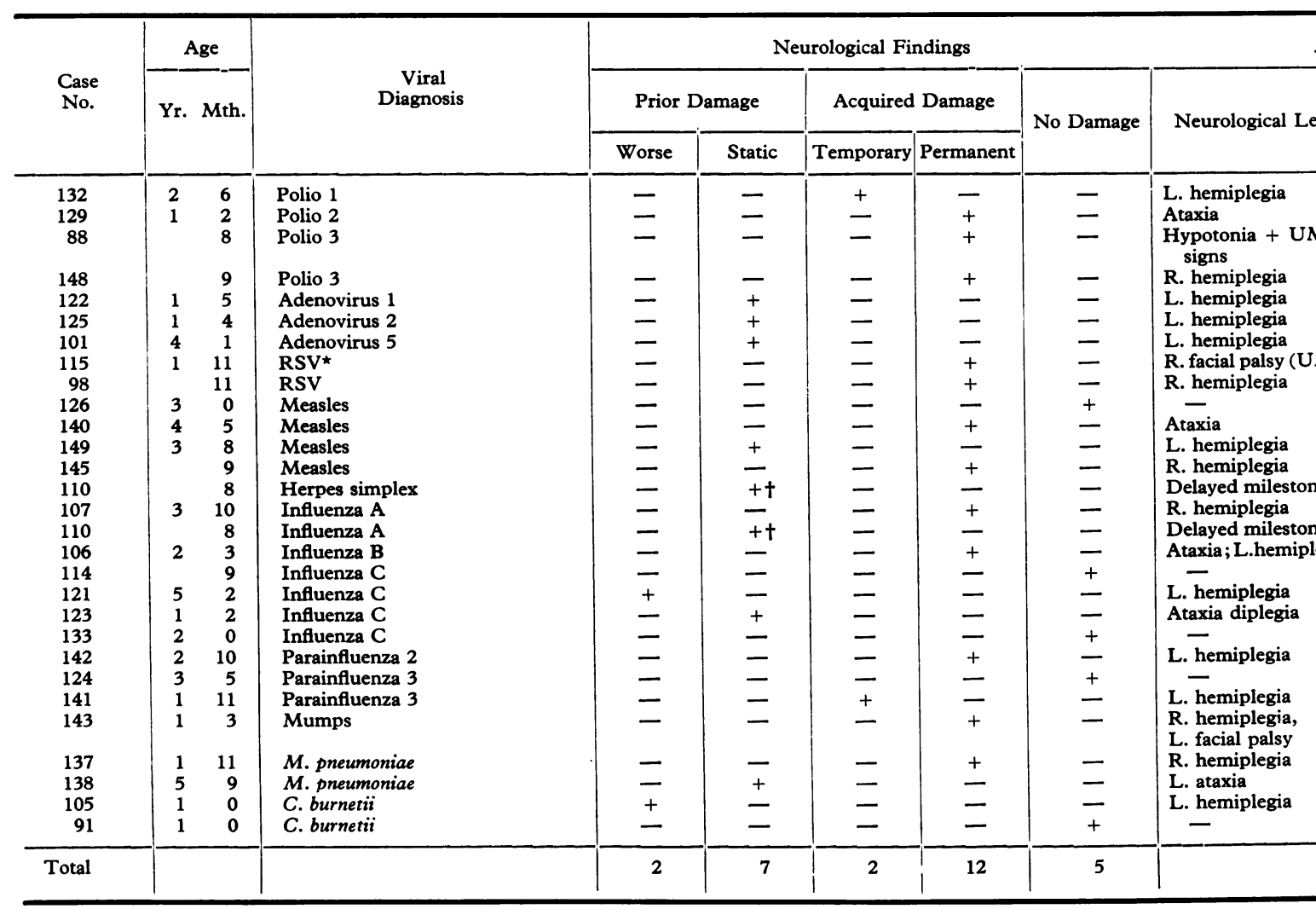
$\stackrel{1}{+}$ 으

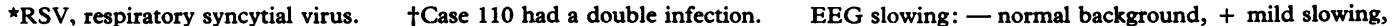
++ moderate slowing, +++ marked slowing. UMN, upper motor neurone.

were more likely to persist if the child had had a fit. Focal abnormalities were found much more often in group A and B children, but occurred also in groups C and D. Spikes and epileptic bursts were confined to the records of children from groups $A$ and B. Persistence of spikes to the best record occurred in group A only. Return to normal within 4 days was seen significantly more often in groups $\mathrm{B}$ and $\mathrm{D}$ than in groups $\mathrm{A}$ and $\mathrm{C}\left(\chi^{2} 4 \cdot 1 \mathrm{p}<0 \cdot 05\right)$.

The initial EEGs were not the most abnormal obtained in 14 children's series (group A, 6; group B, 6; and group C, 2 patients). In Cases 137, 142, and 145, EEG deterioration was simultaneous with the appearance of their neurological abnormalities. The other 11 children had either improvement or no change in their neurological states during worsening of the EEG. EEGs from the series of Cases $C 9$ and 142 are shown in Fig. 3 and 4.

The lengths of follow-up of EEGs in groups A and B were comparable. $32 \%$ (10) group A and $64 \%$ (16) group B patients eventually had completely normal records $\left(\chi^{2}=3.9, \mathrm{p}<0.05\right.$, significant). An additional 53\% (15) group $A$ and $32 \%$ (8) group $B$ children achieved normal background activity, but with superadded abnormalities. The follow-ups of 17 group $C$ and all group D children were also comparable, but were over a shorter period of time than groups A and B. $23 \%$ (4) group $\mathrm{C}$ and $86 \%$ (6) group D children achieved completely normal records. (The numbers in group D as a whole are too small to make statistical analysis valid.) A further $71 \%$ (12) group $C$ and $14 \%$ (1) group $\mathrm{D}$ had normal background activity on their final tracings.

\section{Discussion}

Infection with enteroviruses (poliovirus 1, 2, 3, ECHO 1, 3, 4, 6, 7, 9, 19, and Coxsackie virus A2, 
IA

ndings in 28 Children with Fits and Positive Viral Findings

\begin{tabular}{|c|c|c|c|c|c|c|c|c|c|c|c|}
\hline \multicolumn{6}{|c|}{ 'Worst' EEG in 1st 4 Days } & \multicolumn{6}{|c|}{ 'Best' EEG in 1st 4 Days } \\
\hline Slowing & $\begin{array}{l}\text { Asym- } \\
\text { metry }\end{array}$ & $\begin{array}{l}\text { Runs } \\
\text { Slower } \\
\text { Activity }\end{array}$ & $\begin{array}{l}\text { Focal } \\
\text { Abnor- } \\
\text { mality }\end{array}$ & $\begin{array}{c}\text { Spikes } \\
\text { Epileptic } \\
\text { Bursts }\end{array}$ & $\begin{array}{l}\text { Normal } \\
\text { Record }\end{array}$ & Slowing & $\begin{array}{l}\text { Asym- } \\
\text { metry }\end{array}$ & $\begin{array}{c}\text { Runs } \\
\text { Slower } \\
\text { Activity }\end{array}$ & $\begin{array}{l}\text { Focal } \\
\text { Abnor- } \\
\text { mality }\end{array}$ & $\begin{array}{c}\text { Spikes } \\
\text { Epileptic } \\
\text { Bursts }\end{array}$ & $\begin{array}{l}\text { Normal } \\
\text { Record }\end{array}$ \\
\hline - & + & 一 & 一 & - & - & - & - & - & - & - & + \\
\hline - & 一 & + & + & 一 & - & - & 一 & + & 一 & - & - \\
\hline+++ & + & + & 一 & + & - & +++ & + & + & - & - & 一 \\
\hline++ & + & + & + & + & 一 & + & + & + & + & 一 & 一 \\
\hline+ & - & + & + & 一 & - & 一 & 一 & + & 一 & 一 & 一 \\
\hline+ & - & + & + & 一 & 一 & + & - & + & - & 一 & 一 \\
\hline++ & + & + & + & - & - & Only one & ecord pri & to 4 days & & & \\
\hline++ & + & + & + & - & 一 & ++ & + & + & + & - & - \\
\hline++ & + & + & + & + & - & ++ & + & + & + & - & - \\
\hline+ & + & + & + & - & - & + & + & + & + & - & - \\
\hline++ & + & + & + & - & - & + & + & + & - & - & - \\
\hline+ & - & + & + & - & - & + & 一 & + & - & - & - \\
\hline$+t$ & - & + & + & - & $\overline{+t}$ & - & - & + & + & - & - \\
\hline$+t$ & - & $\bar{t}$ & + & $\bar{t}$ & + T & $\overline{t+}$ & - & $\bar{t}$ & $\overline{+}$ & - & $\stackrel{+t}{-}$ \\
\hline - & - & 一 & 一 & 一 & $+t$ & - & - & 一 & - & - & $+t$ \\
\hline++ & + & + & + & + & - & ++ & + & + & + & - & - \\
\hline$\overline{1+}$ & \pm & + & \pm & - & 二 & - & + & + & - & - & - \\
\hline $\begin{array}{c}+t \\
+\end{array}$ & - & $\begin{array}{l}+ \\
+\end{array}$ & $\bar{t}$ & - & - & $\overline{t+}$ & - & \pm & - & - & - \\
\hline- & + & - & - & - & - & - & - & - & - & - & + \\
\hline++ & + & + & - & 一 & 一 & ++ & - & + & 一 & - & - \\
\hline++ & - & + & + & - & 一 & 一 & + & + & + & - & - \\
\hline++ & + & 一 & - & - & 一 & - & + & 一 & - & - & - \\
\hline++ & + & + & + & - & - & ++ & + & + & + & - & - \\
\hline++ & - & + & - & - & - & + & - & + & - & - & - \\
\hline+ & + & + & + & 一 & 一 & 一 & - & + & 一 & - & 一 \\
\hline++ & + & + & + & + & - & ++ & + & + & + & + & - \\
\hline - & - & - & - & - & + & - & - & - & - & - & + \\
\hline 22 & 16 & 23 & 19 & 6 & 2 & 15 & 12 & 21 & 10 & 1 & 4 \\
\hline
\end{tabular}

A9, B1-5), measles, mumps, rubella, varicella, influenza $A, B$, herpes simplex and zoster, and adenovirus has been reported in association with clinical encephalitis, or abnormal EEGs without clinical evidence of central nervous system disease (Ager et al., 1964; Artenstein, Cadigan, and Buescher, 1964; Bell et al., 1964; Blackwood et al. 1966; Brewis, 1954; Crandell et al., 1968; Flewett and Hoult, 1958; Gibbs et al., 1964; Grossman et al., 1955; Grossman, Gibbs, and Spies, 1958; Heathfield et al., 1967; Holliday, 1950; Kennedy and Wanglee, 1967; Lepow et al., 1962; McConkey and Daws, 1958; McKendrick, 1968; Meyer et al., 1960; Miller, Stanton, and Gibbons, 1956; Miller and Ross, 1968; Moura Ribeiro and Moura Ribeiro, 1968; Pampiglione, 1964; Stern, 1961; Williams et al., 1968; Wilson, 1968). The mycoplasmas have also been implicated as encephalitic agents (Chanock et al., 1960; Sköldenberg, 1965).
The present study underlines the importance of viral infection as a cause of neurological disease in childhood.

Though the differences between the groups are not statistically significant for abnormal birth history, positive family history of fits, or evidence of prior neurological damage, group $A$ and $B$ children had a higher incidence of these factors than group $C$ and $D$ children, any of which might lead to a predisposition to fits. 11 group $A$ children and 7 group B children were without such factors $\chi^{2}=0 \cdot 7$, not significant). Evidence from the neurological and EEG studies suggests that lack of a significant difference here does not preclude the likelihood that at least some of the 11 group A children had fits primarily as a result of infection with a virus, and that predisposed members of group A had fits precipitated by such an infection. Somewhat surprisingly, children with prior neuro- 
TABI曾

Group B; Neurological, EEG, Bacteriological, $\frac{\partial}{\partial+}$

\begin{tabular}{|c|c|c|c|c|c|c|c|c|c|}
\hline \multirow{3}{*}{$\begin{array}{l}\text { Case } \\
\text { No. }\end{array}$} & \multirow{2}{*}{\multicolumn{2}{|c|}{ Age }} & \multirow{3}{*}{$\begin{array}{c}\text { Bacteriological } \\
\text { or } \\
\text { Clinical } \\
\text { Diagnosis }\end{array}$} & \multicolumn{6}{|c|}{ Neurological Findings } \\
\hline & & & & \multicolumn{2}{|c|}{ Prior Damage } & \multicolumn{2}{|c|}{ Acquired Damage } & \multirow{2}{*}{ No Damage } & \multirow{2}{*}{ Neurological Lesio } \\
\hline & Yr. & Mth. & & Worse & Static & Temporary & Permanent & & \\
\hline 136 & 1 & 8 & Upper resp. tract infect. & 一 & 一 & 一 & + & - & Ataxia \\
\hline 147 & & 9 & Upper resp. tract infect. & 一 & - & 一 & + & 一 & L.facial palsy (UN \\
\hline 89 & 1 & 6 & Upper resp. tract infect. & - & 一 & + & - & 一 & L. facial palsy (UN \\
\hline 97 & 4 & 5 & Upper resp. tract infect. & - & 一 & + & 一 & - & L. hemiplegia \\
\hline 103 & 1 & 4 & Upper resp. tract infect. & - & - & + & - & - & Ataxia \\
\hline 113 & & 11 & Upper resp. tract infect. & 一 & - & + & 一 & 一 & L. hemiplegia \\
\hline 127 & 2 & 11 & Upper resp. tract infect. & - & 一 & + & 一 & 一 & L. hemiplegia \\
\hline 146 & 2 & 2 & Upper resp. tract infect. & 一 & - & + & 一 & 一 & R. hemiplegia \\
\hline 93 & 2 & 8 & Upper resp. tract infect. & - & 一 & - & - & + & - \\
\hline 95 & 1 & 0 & Upper resp. tract infect. & - & 一 & - & 一 & + & - \\
\hline 109 & 2 & 0 & Upper resp. tract infect. & - & - & - & - & + & - \\
\hline 90 & 1 & 7 & Upper resp. tract infect. & - & + & - & - & - & Diplegia \\
\hline 99 & 2 & 3 & Upper resp. tract infect. & - & + & - & - & - & Delayed mileston \\
\hline 117 & 2 & 4 & Upper resp. tract infect. & - & + & - & 一 & 一 & Ataxic diplegia \\
\hline 128 & & 11 & Upper resp. tract infect. & - & + & 一 & - & - & L. hemiplegia \\
\hline 134 & 2 & 4 & Upper resp. tract infect. & + & - & - & - & - & Diplegia \\
\hline 139 & $\overline{1}$ & 10 & Upper resp. tract infect. & - & + & 一 & - & - & LMN L. facial p \\
\hline 112 & 1 & 7 & Lower resp. tract infect. & - & - & 一 & - & + & - \\
\hline 94 & 1 & 0 & Lower resp. tract infect. & - & 一 & + & 一 & - & Ataxia \\
\hline 96 & 5 & 6 & Encephalitis & - & - & & + & - & $\begin{array}{l}\text { Hypotonia + UM } \\
\text { signs }\end{array}$ \\
\hline 118 & 1 & 0 & Encephalitis & - & - & + & - & - & UMN L. facial p \\
\hline 120 & 1 & 2 & Encephalitis & 一 & 一 & - & + & - & Ataxia \\
\hline 135 & 2 & 1 & Encephalitis & 一 & - & - & + & - & Hypotonia + UM \\
\hline 116 & 1 & 10 & Urinary infect. (E. coli) & + & - & - & - & - & L. hemiplegia \\
\hline 144 & 5 & 8 & Erysipelas (Strep. pyogenes) & + & - & - & - & 一 & R. hemiplegia \\
\hline Total & & & & 3 & 5 & 8 & 5 & 4 & \\
\hline
\end{tabular}

LMN, UMN, lower or upper motor neurone.

TABEI

站

. facial palsy (UM

Ataxia

L. hemiplegia

Diplegia

ilestoniss

L. hemiplegia

Diplegia

Ataxia

y UMf

tonia + UMd

Group C; Neurological, EEG, and Virologisa

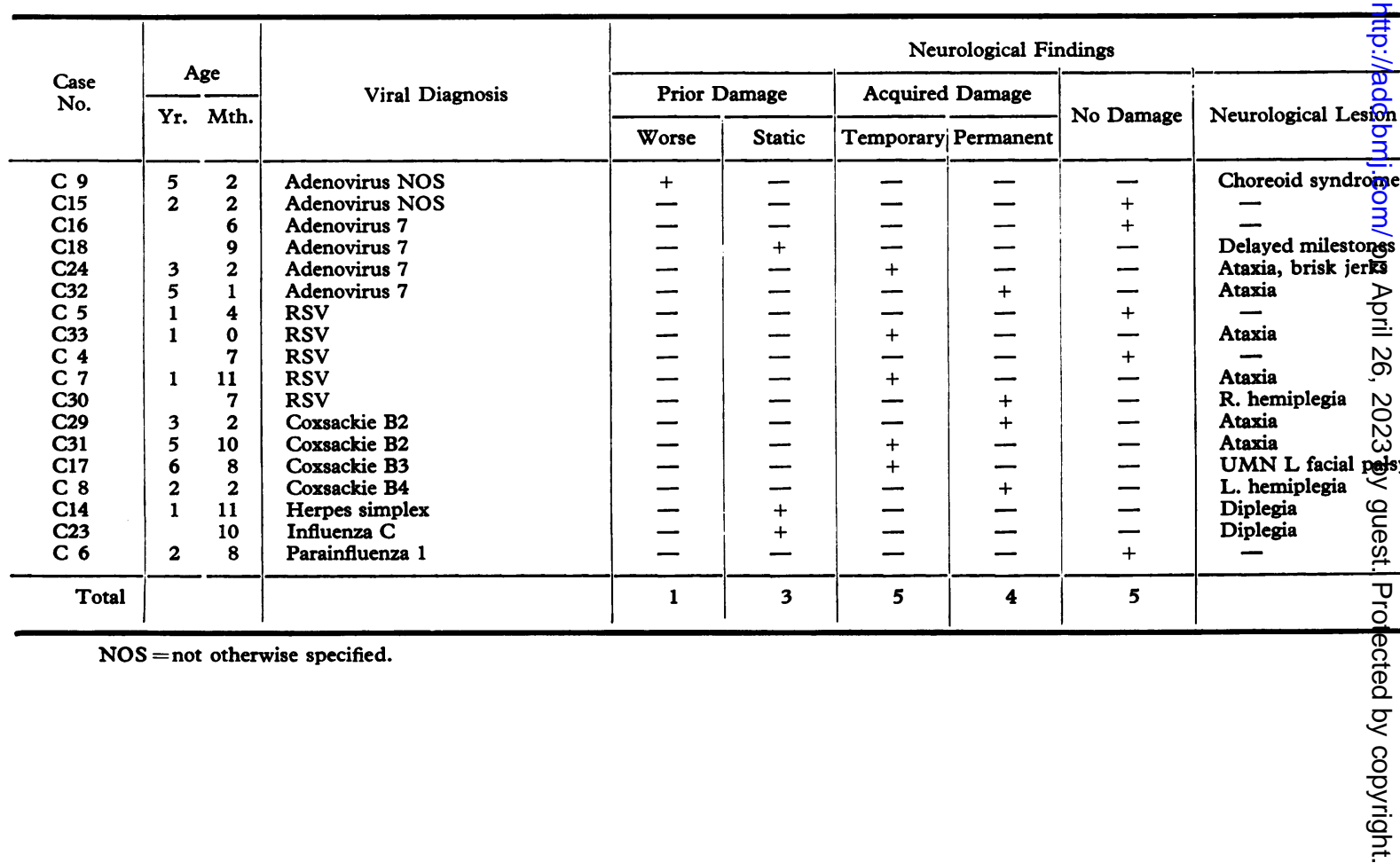


Jlinical Findings in 25 Children with Fits and Negative Viral Findings

\begin{tabular}{|c|c|c|c|c|c|c|c|c|c|c|c|}
\hline \multicolumn{6}{|c|}{ 'Worst' EEG in 1st 4 Days } & \multicolumn{6}{|c|}{ 'Best' EEG in 1st 4 Days } \\
\hline Slowing & $\begin{array}{l}\text { Asym- } \\
\text { metry }\end{array}$ & $\begin{array}{c}\text { Runs } \\
\text { Slower } \\
\text { Activity }\end{array}$ & $\begin{array}{l}\text { Focal } \\
\text { Abnor- } \\
\text { mality }\end{array}$ & $\begin{array}{c}\text { Spikes } \\
\text { Epileptic } \\
\text { Bursts }\end{array}$ & $\begin{array}{l}\text { Normal } \\
\text { Record }\end{array}$ & Slowing & $\begin{array}{l}\text { Asym- } \\
\text { metry }\end{array}$ & $\begin{array}{c}\text { Runs } \\
\text { Slower } \\
\text { Activity }\end{array}$ & $\begin{array}{l}\text { Focal } \\
\text { Abnor- } \\
\text { mality }\end{array}$ & $\begin{array}{c}\text { Spikes } \\
\text { Epileptic } \\
\text { Bursts }\end{array}$ & $\begin{array}{l}\text { Normal } \\
\text { Record }\end{array}$ \\
\hline 一 & 一 & 一 & 一 & 一 & + & - & - & - & 一 & - & + \\
\hline 一 & - & 一 & 一 & 一 & + & - & - & 一 & 一 & 一 & + \\
\hline+ & 一 & + & + & - & - & 一 & 一 & + & - & 一 & - \\
\hline 一 & + & + & - & - & - & 一 & 一 & + & 一 & 一 & - \\
\hline - & - & + & + & - & 一 & - & - & 一 & 一 & 一 & + \\
\hline++ & + & + & + & - & - & - & + & + & + & - & - \\
\hline++ & - & + & + & - & - & + & - & + & - & - & - \\
\hline++ & + & + & + & + & - & + & - & + & - & - & 一 \\
\hline+ & - & + & + & + & - & - & - & - & - & - & + \\
\hline - & 一 & + & + & - & - & - & - & + & - & - & - \\
\hline - & - & + & - & - & - & - & - & + & - & - & - \\
\hline - & + & - & - & - & - & 一 & - & - & - & 一 & + \\
\hline++ & + & + & + & - & - & + & + & + & - & - & - \\
\hline+ & - & + & - & - & - & - & + & - & - & - & - \\
\hline - & - & + & + & - & - & $\longrightarrow$ & - & + & - & 一 & - \\
\hline++ & 一 & 一 & - & - & - & - & - & - & - & - & + \\
\hline - & - & - & - & - & + & Only on & ecord in & t 4 days & & & \\
\hline - & - & + & - & - & - & - & - & - & - & 一 & + \\
\hline- & + & + & - & - & - & - & 一 & + & + & - & - \\
\hline$+t+$ & + & - & - & - & - & ++ & - & - & + & - & - \\
\hline+ & + & + & + & - & 一 & - & + & + & + & - & - \\
\hline++ & 一 & - & - & - & - & Only on & ecord in & 4 days & & & \\
\hline++ & - & + & - & - & - & - & 一 & + & - & - & - \\
\hline++ & + & + & + & - & - & ++ & + & + & - & - & - \\
\hline+ & + & + & + & - & - & + & - & + & + & - & - \\
\hline 14 & 10 & 18 & 12 & 2 & 3 & 6 & 5 & 14 & 5 & 0 & 7 \\
\hline
\end{tabular}

VIIC

Findings in 18 Control Children with Positive Viral Findings

\begin{tabular}{|c|c|c|c|c|c|c|c|c|c|c|c|}
\hline \multicolumn{6}{|c|}{ 'Worst' EEG in 1st 4 Days } & \multicolumn{6}{|c|}{ 'Best' EEG in 1st 4 Days } \\
\hline Slowing & $\begin{array}{l}\text { Asym- } \\
\text { metry }\end{array}$ & $\begin{array}{c}\text { Runs } \\
\text { Slower } \\
\text { Activity }\end{array}$ & $\begin{array}{l}\text { Focal } \\
\text { Abnor- } \\
\text { mality }\end{array}$ & $\begin{array}{l}\text { Spikes } \\
\text { Epileptic } \\
\text { Bursts }\end{array}$ & $\begin{array}{l}\text { Normal } \\
\text { Record }\end{array}$ & Slowing & $\begin{array}{l}\text { Asym- } \\
\text { metry }\end{array}$ & $\begin{array}{c}\text { Runs } \\
\text { Slower } \\
\text { Activity }\end{array}$ & $\begin{array}{l}\text { Focal } \\
\text { Abnor- } \\
\text { mality }\end{array}$ & $\begin{array}{c}\text { Spikes } \\
\text { Epileptic } \\
\text { Bursts }\end{array}$ & $\begin{array}{l}\text { Normal } \\
\text { Record }\end{array}$ \\
\hline+++ & - & - & - & - & - & ++ & - & - & - & 一 & - \\
\hline++ & - & + & - & - & - & - & - & - & - & - & + \\
\hline++ & - & - & - & - & - & ++ & - & - & - & - & - \\
\hline+ & - & - & - & - & - & + & - & - & - & - & - \\
\hline++ & - & + & - & - & - & \multicolumn{3}{|c|}{ Only one record in first 4 days } & & & \\
\hline+++ & - & + & - & - & - & +++ & - & + & - & - & - \\
\hline++ & - & - & - & - & - & \multirow{4}{*}{\multicolumn{3}{|c|}{$\begin{array}{l}\text { Only one record in first } 4 \text { days } \\
\text { Only one record in first } 4 \text { days } \\
\text { Only one record in first } 4 \text { days } \\
\text { Only one record in first } 4 \text { days }\end{array}$}} & & & \\
\hline++ & - & - & - & - & - & & & & & & \\
\hline - & - & - & - & - & + & & & & & & \\
\hline+ & - & + & - & - & - & & & & & & \\
\hline$++t$ & - & - & - & - & - & - & - & - & - & - & + \\
\hline - & - & + & - & - & - & - & - & - & - & - & + \\
\hline++ & - & + & - & - & - & + & - & - & - & - & - \\
\hline - & - & - & + & - & - & \multicolumn{3}{|c|}{ Only one record in first 4 days } & & & \\
\hline++ & - & - & + & - & - & + & - & - & + & - & - \\
\hline+++ & - & + & - & - & - & ++ & - & + & - & - & - \\
\hline - & + & - & - & 一 & - & - & - & + & - & - & - \\
\hline++ & 一 & - & + & 一 & 一 & ++ & - & - & - & - & - \\
\hline 14 & 1 & 7 & 3 & $\mathbf{0}$ & 1 & 8 & $\mathbf{0}$ & 3 & 1 & 0 & 3 \\
\hline
\end{tabular}


Group D; Neurological, EEG, Bacteriological,

\begin{tabular}{|c|c|c|c|c|c|c|c|c|c|}
\hline \multirow{3}{*}{$\begin{array}{l}\text { Case } \\
\text { No. }\end{array}$} & \multicolumn{2}{|c|}{ Age } & \multirow{3}{*}{$\begin{array}{c}\text { Bacteriological } \\
\text { or } \\
\text { Clinical } \\
\text { Diagnosis }\end{array}$} & \multicolumn{6}{|c|}{ Neurological Findings } \\
\hline & \multirow{2}{*}{\multicolumn{2}{|c|}{ Yr. Mth. }} & & \multicolumn{2}{|c|}{ Prior Damage } & \multicolumn{2}{|c|}{ Acquired Damage } & \multirow{2}{*}{ No Damage } & \multirow[t]{2}{*}{ Neurological Le } \\
\hline & & & & Worse & Static & Temporary & Permanent & & \\
\hline $\begin{array}{l}\text { C20 } \\
\text { C22 } \\
\text { C27 } \\
\text { C10 } \\
\text { C12 } \\
\text { C } 1 \\
\text { C } 3\end{array}$ & $\begin{array}{l}1 \\
4 \\
1 \\
2 \\
2\end{array}$ & $\begin{array}{r}4 \\
2 \\
6 \\
7 \\
9 \\
7 \\
11\end{array}$ & $\begin{array}{l}\text { Upper resp. tract infect. } \\
\text { Upper resp. tract infect. } \\
\text { Lower resp. tract infect. } \\
\text { Pneumococcal empyema } \\
\text { Meningitis (H. influenzae) } \\
\text { Septic arthritis (Staph. aureus) } \\
\text { Appendix abscess }\end{array}$ & $\begin{array}{l}\bar{z} \\
\bar{z} \\
\bar{z}\end{array}$ & $\begin{array}{l}\bar{z} \\
\bar{z} \\
\bar{z}\end{array}$ & $\begin{array}{l}\bar{z} \\
\pm \\
\bar{z}\end{array}$ & $\begin{array}{l}= \\
\bar{z} \\
\bar{z}\end{array}$ & $\begin{array}{l}+ \\
+ \\
+ \\
+ \\
+ \\
+\end{array}$ & $\begin{array}{l}\bar{z} \\
\text { Ataxia } \\
\overline{-} \\
\overline{-}\end{array}$ \\
\hline Total & & & & 0 & 0 & 1 & 0 & 6 & \\
\hline
\end{tabular}

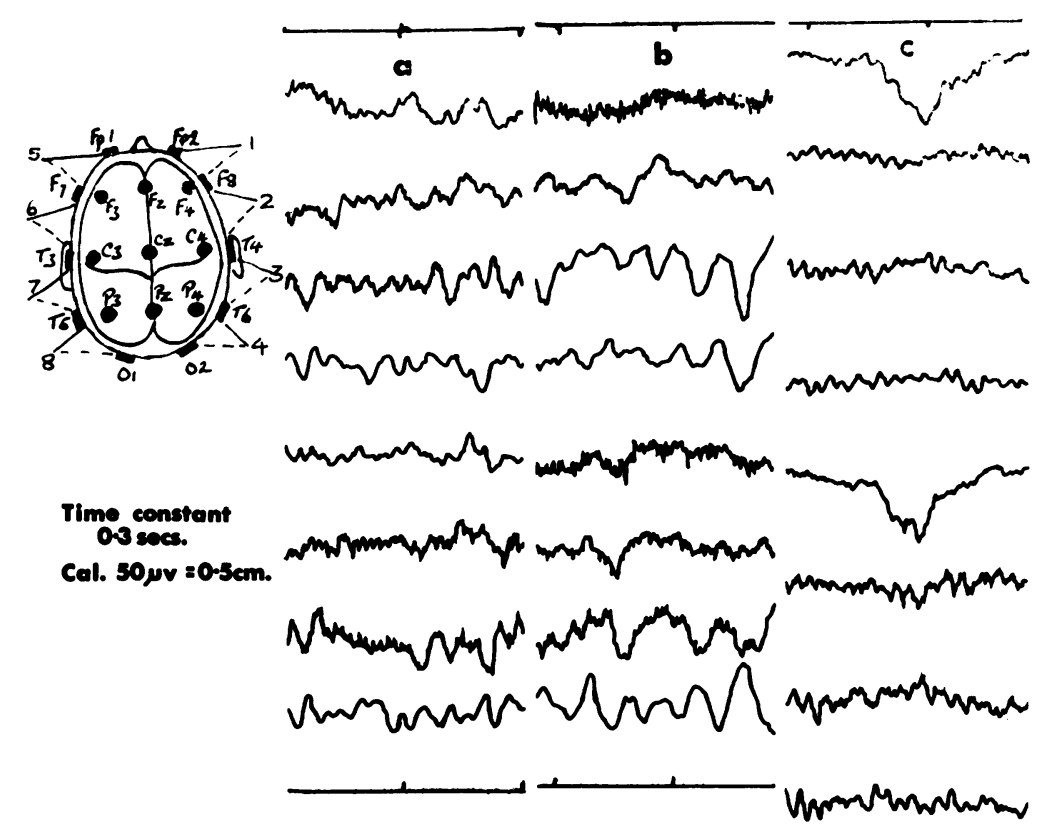

FIG. 3.-EEGs from Case C9. All records: eyes closed. Times from admission to hospital: (a) 1 hour $\left(T 38 \cdot 4^{\circ} \mathrm{C}\right.$.), (b) 42 hours (apyrexial), (c) 14 days.

logical damage do not necessarily convulse even if they have moderate or severe EEG changes in association with a viral infection (Cases C9 and C14). Non-febrile fits, subsequent to the initial illness occur more commonly in patients who have prolonged, repeated, or focal fits than in those who have had one short generalized attack (Lennox, 1949; Ounsted, Lindsay, and Norman, 1966). Two-thirds of the children with fits in association with a viral infection had prolonged, repeated, or focal, fits (Table VI).
It was not possible to arrange that the control children be investigated at the same time as those who had fits. The viruses obtained were a reflection of those in the community at the time, and the findings do not show that those associated with illnesses in the children with fits necessarily differ from those associated with illnesses suffered by children who do not have fits.

Viral infection appears to play an important part in the determination of neurological signs. The children with positive viral findings, whether 


\begin{tabular}{|c|c|c|c|c|c|c|c|c|c|c|c|}
\hline \multicolumn{6}{|c|}{ 'Worst' EEG in 1st 4 Days } & \multicolumn{6}{|c|}{ 'Best' EEG in 1st 4 Days } \\
\hline Slowing & $\begin{array}{l}\text { Asym- } \\
\text { metry }\end{array}$ & $\begin{array}{l}\text { Runs } \\
\text { Slower } \\
\text { Activity }\end{array}$ & $\begin{array}{l}\text { Focal } \\
\text { Abnor- } \\
\text { mality }\end{array}$ & $\begin{array}{c}\text { Spikes } \\
\text { Epileptic } \\
\text { Bursts }\end{array}$ & $\begin{array}{l}\text { Normal } \\
\text { Record }\end{array}$ & Slowing & $\begin{array}{l}\text { Asym- } \\
\text { metry }\end{array}$ & $\begin{array}{l}\text { Runs } \\
\text { Slower } \\
\text { Activity }\end{array}$ & $\begin{array}{l}\text { Focal } \\
\text { Abnor- } \\
\text { mality }\end{array}$ & $\begin{array}{c}\text { Spikes } \\
\text { Epileptic } \\
\text { Bursts }\end{array}$ & $\begin{array}{l}\text { Normal } \\
\text { Record }\end{array}$ \\
\hline- & - & + & - & - & + & \multicolumn{3}{|c|}{$\begin{array}{l}\text { Only one record in first } 4 \text { days } \\
\text { Only one record in first } 4 \text { days }\end{array}$} & & & \\
\hline+ & - & - & + & - & - & - & - & - & - & - & + \\
\hline- & - & + & - & - & - & - & - & + & - & 一 & - \\
\hline++ & - & + & - & 一 & - & ++ & - & - & - & - & - \\
\hline- & - & + & - & - & - & Only on & ecord in & st 4 days & & & \\
\hline - & - & - & - & - & + & - & - & - & - & - & + \\
\hline 2 & 0 & 4 & 1 & 0 & 2 & 1 & 0 & 1 & 0 & 0 & 2 \\
\hline
\end{tabular}

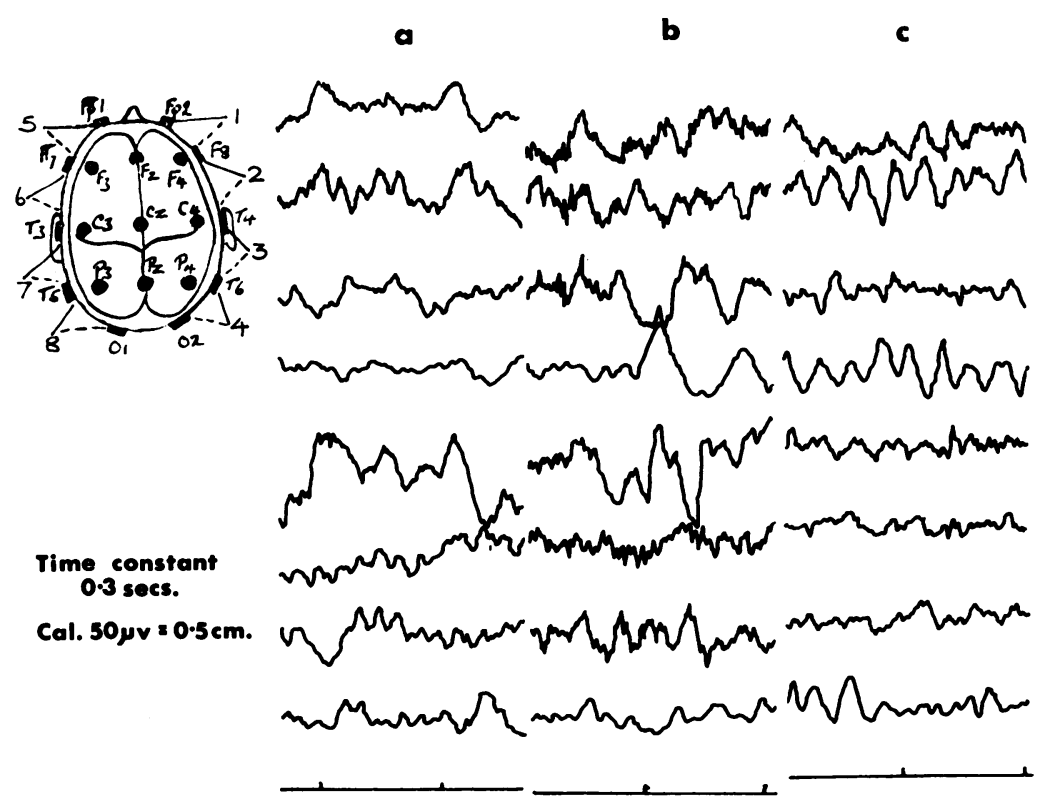

FIG. 4.-EEGs from Case 142. All records: eyes open (apyrexial). Times from admission to hospital: (a) 3 days, (b) 5 days, (c) 10 days.

associated with fits or not (groups $\mathrm{A}$ and $\mathrm{C}$ ) were significantly more likely to acquire permanent damage than those with negative viral findings (groups B and D) $\left(x^{2} 4 \cdot 1, \mathrm{p}<0 \cdot 05\right)$. The presence of both fits and a viral infection carried the most serious prognosis. $57 \%$ of the 21 children who acquired permanent abnormal signs belonged to group $\mathrm{A}$, as opposed to $36 \%$ of all 78 children $\left(\chi^{2} 5 \cdot 8, \mathrm{p}<0.025\right.$, significant). In contrast, $25 \%$ (5) of the children who showed no abnormal signs came from group $\mathrm{A}\left(\chi^{2} 1 \cdot 4\right.$, not significant). No control child with negative virology acquired permanent neurological damage, and $86 \%$ (6) showed no evidence of damage at any time. Among the children with unremitting signs, evidence was found of infection with the following organisms which have not previously been reported in association with neurological damage: adenovirus $7, \mathrm{RSV}$, parainfluenza 2, and C. burnetii ( $Q$ fever). It is possible that other viruses whose clinical manifestations are usually confined to the respiratory tract may, on occasions, produce central nervous system disturbance.

Slowing of the background activity of the EEG in 
TABLE VIII

Percentage and Number of Children in Each Group with Specific EEG Findings in the First Four Days

\begin{tabular}{|c|c|c|c|c|c|c|c|c|c|c|c|c|c|c|c|c|c|}
\hline \multicolumn{4}{|c|}{ Group } & \multicolumn{2}{|c|}{ Slowing } & \multicolumn{2}{|c|}{$\begin{array}{c}\text { Slow } \\
++t+t\end{array}$} & \multicolumn{2}{|c|}{$\begin{array}{c}\text { Runs Slower } \\
\text { Activity }\end{array}$} & \multicolumn{2}{|c|}{ Asymmetry } & \multicolumn{2}{|c|}{$\begin{array}{c}\text { Focal } \\
\text { Abnormality }\end{array}$} & \multicolumn{2}{|c|}{$\begin{array}{c}\text { Spikes } \\
\text { Epileptic } \\
\text { Bursts }\end{array}$} & \multicolumn{2}{|c|}{$\begin{array}{l}\text { Ncrmal } \\
\text { Record }\end{array}$} \\
\hline & & & & $\%$ & No. & $\%$ & No. & $\%$ & No. & $\%$ & No. & $\%$ & No. & $\%$ & No. & $\%$ & No. \\
\hline $\begin{array}{c}\text { ‘Worst' EEG } \\
\text { A ( } 28 \text { cases }) \\
\text { B ( } 25 \text { cases }) \\
\text { C (18 cases }) \\
\text { D ( } 7 \text { cases })\end{array}$ & $\begin{array}{l} \\
\ldots \\
\ldots \\
\ldots\end{array}$ & $\begin{array}{l}\ldots \\
\cdots \\
\cdots \\
\ldots\end{array}$ & $\begin{array}{l}\ldots \\
\cdots \\
\ldots\end{array}$ & $\begin{array}{l}79 \\
54 \\
78 \\
29\end{array}$ & $\begin{array}{r}22 \\
14 \\
14 \\
2\end{array}$ & $\begin{array}{l}57 \\
36 \\
67 \\
14\end{array}$ & $\begin{array}{r}16 \\
9 \\
12 \\
1\end{array}$ & $\begin{array}{l}82 \\
72 \\
39 \\
57\end{array}$ & $\begin{array}{r}23 \\
18 \\
7 \\
4\end{array}$ & $\begin{array}{r}57 \\
40 \\
6 \\
0\end{array}$ & $\begin{array}{r}16 \\
10 \\
1 \\
0\end{array}$ & $\begin{array}{l}68 \\
48 \\
17 \\
14\end{array}$ & $\begin{array}{r}19 \\
12 \\
3 \\
1\end{array}$ & $\begin{array}{r}21 \\
8 \\
0 \\
0\end{array}$ & $\begin{array}{l}6 \\
2 \\
0 \\
0\end{array}$ & $\begin{array}{r}7 \\
12 \\
6 \\
29\end{array}$ & $\begin{array}{l}2 \\
3 \\
1 \\
2\end{array}$ \\
\hline $\begin{array}{c}\text { 'Best' EEG } \\
\text { A ( } 27 \text { cases }) \\
\text { B ( } 23 \text { cases }) \\
\text { C (12 cases }) \\
\text { D ( } 4 \text { cases })\end{array}$ & $\begin{array}{l}\ldots \\
\ldots \\
\ldots\end{array}$ & $\begin{array}{l}\cdots \\
\cdots \\
\cdots \\
\cdots\end{array}$ & $\begin{array}{l}\ldots \\
\ldots \\
\ldots\end{array}$ & $\begin{array}{l}56 \\
26 \\
67 \\
25\end{array}$ & $\begin{array}{r}15 \\
6 \\
8 \\
1\end{array}$ & $\begin{array}{r}33 \\
9 \\
42 \\
25\end{array}$ & $\begin{array}{l}9 \\
2 \\
5 \\
1\end{array}$ & $\begin{array}{l}78 \\
61 \\
25 \\
25\end{array}$ & $\begin{array}{r}21 \\
14 \\
3 \\
1\end{array}$ & $\begin{array}{r}44 \\
22 \\
0 \\
0\end{array}$ & $\begin{array}{r}12 \\
5 \\
0 \\
0\end{array}$ & $\begin{array}{r}37 \\
22 \\
8 \\
0\end{array}$ & $\begin{array}{r}10 \\
5 \\
1 \\
0\end{array}$ & $\begin{array}{l}4 \\
0 \\
0 \\
0\end{array}$ & $\begin{array}{l}1 \\
0 \\
0 \\
0\end{array}$ & $\begin{array}{l}15 \\
30 \\
25 \\
50\end{array}$ & $\begin{array}{l}1 \\
7 \\
3 \\
2\end{array}$ \\
\hline
\end{tabular}

febrile children without fits has been described by Lennox (1953), and, more specifically in measles, by Grossman et al. (1955), Pampiglione (1964), and Moura Ribeiro and Moura Ribeiro (1968). Gibbs et al. (1959) described EEG changes in children with measles, mumps, rubella, and scarlet fever, but no viral or bacterial confirmations of the diagnoses were given. All these conditions were associated with EEG abnormalities in some cases, but, since some of the 'clinically normal' children had fits, it is difficult to assess their findings. Grossman et al. (1958) found EEG changes in 48 of 111 patients with poliomyelitis who had no clinical evidence of encephalitis. Sköldenberg (1965) reports slow dysfunction in patients' EEGs during infection with $M$. pneumoniae. In the present study, it was of considerable interest to find that viral infections (group C) were more important than fits (group B) in the determination of the speed of the dominant EEG rhythm and the return of this to normal. Though background asymmetry, runs of slower activity, and focal abnormalities occurred more often in children with fits, and epileptic activity in the form of isolated spikes or generalized bursts was confined to these children, the percentages of all these abnormalities were highest in group $\mathrm{A}$, adding further emphasis to the cerebral pathogenicity of viruses. It seems likely that the fits which many group A patients suffered were a symptom of virological brain disturbance, and it is suggested that the diagnosis of encephalitis should be considered more frequently in children who are classified as having 'febrile convulsions'.

The presence of transient focal EEG abnormalities in group $\mathrm{C}$ and $\mathrm{D}$ children with respiratory tract infections, and the acquisition of permanent neurological damage in children from group C, suggests that apparently innocuous illnesses in childhood can cause cerebral dysfunction which, later, might be associated with epilepsy, minor motor disability, or behaviour disturbances.

We wish to thank, at the Royal Hospital for Sick Children, Edinburgh, all the paediatricians, for access to patients, the EEG recordists, and Professor J. O. Forfar and Dr. T. T. S. Ingram, for advice on preparation of the manuscript; and, at the Wellcome Laboratory, Edinburgh, Dr. Margaret A. J. Moffat, Dr. Sheila M. Stewart, and their staff for virological and mycoplasma results.

S.J.W. was in receipt of a grant from the fund given to the University of Edinburgh by the Distillers Company.

\section{REFERENCES}

Ager, E. A., Felsenstein, W. C., Alexander, E. R., Wymer, M. E., Sabotta, E., and Ashby, V. (1964). An epidemic of illness due to Coxsackie virus group B, type 2. Fournal of the American Medical Association, 187, 251.

Artenstein, M. S., Cadigan, F. C., Jr., and Buescher, E. L. (1964). Epidemic Coxsackie virus infection with mixed clinical manifestations. Annals of Internal Medicine, 60, 196.

Bell, M., Crooks, J., Mohamed, S. D., and Stephens, S. A. (1964). Group B Coxsackie viruses in North-East Scotland. Scottish Medical fournal, 9, 491.

Blackwood, W., Dudgeon, J. A., Newns, G. H., and Phillips, B. M. (1966). A case of encephalitis due to herpes simplex. British Medical fournal, 1, 1519.

Bradstreet, C. M. P., and Taylor, C. E. D. (1962). Technique of complement-fixation test applicable to the diagnosis of virus diseases. Monthly Bulletin of the Ministry of Health, 21, 96.

Brewis, E. G. (1954). Recent experience of encephalitis in childhood. British Medical fournal, 1, 1298.

Chanock, R. M., Cook, M. K., Fox, H. H., Parrott, R. H., and Huebner, R. J. (1960). Serologic evidence of infection with Eaton agent in lower respiratory illness in childhood. New England fournal of Medicine, 262, 648.

Communicable Diseases, Scotland, Report. (1967). Scottish Home and Health Department, Edinburgh.

Crandell, R. A., Dowdle, W. R., Holcomb, T. M., and Dahl, E. V. (1968). A fatal illness associated with two viruses: an intermediate adenovirus type (21-16) and influenza $A_{2}$. Fournal of Pediatrics, 72, 467. 
Flewett, T. H., and Hoult, J. G. (1958). Influenzal encephalopathy and postinfluenzal encephalitis. Lancet, $2,11$.

Gibbs, F. A., Gibbs, E. L., Carpenter, P. R., and Spies, H. W. (1959). EEG abnormality in 'uncomplicated' childhood diseases. Fournal of the American Medical Association, 171, 1050.

- - - Spies, H. W., and Carpenter, P. R. (1964). Common types of childhood encephalitis: electroencephalographic and clinical relationships. Archives of Neurology, 10, 1.

Grist, N. R., Ross, C. A. C., Bell, E. J., and Stott, E. J. (1966). Diagnostic Methods in Clinical Virology. p. 41 Blackwell, Oxford.

Grossman, H. J., Gibbs, E. L., and Spies, H. W. (1958). EEG studies of patients having poliomyelitis with no clinical evidence of encephalitic involvement. Pediatrics, 22, 1148.

-,- , and Lepper, M. H. (1955). EEG studies on children with measles with no clinical evidence of central nervous system involvement. Archives of Neurology and Psychiatry, 73, 576.

Heathfield, K. W. G., Pilsworth, R., Wall, B. J., and Corsellis, J. A. N. (1967). Coxsackie B5 infections in Essex, 1965, with particular reference to the nervous system. Quarterly fournal of Medicine, 36, 579.

Holliday, P. B., Jr. (1950). Pre-eruptive neurological complications of the common contagious diseases-rubella, rubeola, roseola, and varicella. Fournal of Pediatrics, 36, 185.

Kennedy, C., and Wanglee, P. (1967). Encephalitis: a variable syndrome in response to viral infection. Pediatric Clinics of North America, 14, 809.

Lennox, M. A. (1949). Febrile convulsions in childhood: their relationship to adult epilepsy. Fournal of Pediatrics, 35, 427.

Lennox, W. G. (1953). The significance of febrile convulsions. Pediatrics, 11, 341.

Lepow, M. L., Carver, D. H., Wright, H. T., Jr., Woods, W. A., and Robbins, F. C. (1962). A clinical, epidemiologic and laboratory investigation of aseptic meningitis during the four-year period 1955-1958. I. Observations concerning etiology and epidemiology. Nevo England fournal of Medicine, 266, 1181.

McConkey, B., and Daws, R. A. (1958). Neurological disorders associated with Asian influenza. Lancet, 2, 15.
McKendrick, G. D. W. (1968). Encephalitis. (Letter.) Lancet, $1,1248$.

Meyer, H. M., Jr., Johnson, R. T., Crawford, I. P., Dascombe, H. E. and Rogers, N. G. (1960). Central nervous syndromes of 'viral' etiology: a study of 713 cases. American fournal of Medicine, 29, 334.

Miller, H. G., Stanton, J. B., and Gibbons, J. L. (1956). Parainfectious encephalomyelitis and related syndromes. Quarterly fournal of Medicine, 25, 427.

Miller, J. D., and Ross, C. A. C. (1968). Encephalitis: a four-year survey. Lancet, 1, 1121.

Moura Ribeiro, V., and Moura Ribeiro, R. (1968). Evolutive aspects in the EEGs of patients with measles and no neurological signs. Developmental Medicine and Child Neurology, 10, 175.

Neligan, G., and Prudham, D. (1969). Norms for four standard developmental milestones by sex, social class, and place in family. Developmental Medicine and Child Neurology, 11, 413.

Ounsted, C., Lindsay, J., and Norman, R. (1966). Biological factors in temporal lobe epilepsy. Clinics in Developmental Medicine, 22, 50.

Pampiglione, G. (1964). Prodromal phase of measles: some neurophysiological studies. British Medical fournal, 2, 1296.

Sköldenberg, B. (1965). Aseptic meningitis and meningoencephalitis in cold-agglutinin-positive infections. British Medical fournal, $1,100$.

Stern, H. (1961). Aetiology of CNS infections during prevalence of poliovirus and Coxsackie virus: Some clinical manifestations of Coxsackie virus infections. British Medical fournal, 1, 1061.

Williams, H., MacArthur, P., Bell, E. J., and Lamb, R. (1968). Paralysis in echovirus-3 infection. (Letter.) Lancet, 1, 425.

Wilson, J. (1968). Ataxia in childhood. Developmental Medicine and Child Neurology, 10, 388.

Correspondence to Dr. S. J. Wallace, Spina Bifida Unit, Cardiff Royal Infirmary, Newport Road, Cardiff, CF2 1SZ. 